\title{
A new species of Gyrodactylus (Monogenea, Gyrodactylidae), an ectoparasite from the endemic Iranocichla hormuzensis (Teleostei, Cichlidae), the only Iranian cichlid
}

\author{
Maarten P.M. VANHOVE*,1,7, Walter A. BOEGER ${ }^{2}$, Fidel MUTEREZI BUKINGA ${ }^{3}$, \\ Filip A.M. VOLCKAERT ${ }^{4}$, Tine HUYSE ${ }^{5} \&$ Antoine PARISELLE ${ }^{6}$ \\ ${ }^{1,4,5}$ Laboratory of Biodiversity and Evolutionary Genomics, Department of Biology, KU Leuven, \\ Charles Deberiotstraat 32, B-3000 Leuven, Belgium. \\ Emails: maarten.vanhove@bio.kuleuven.be, filip.volckaert@bio.kuleuven.be, \\ tine.huyse@,bio.kuleuven.be \\ ${ }^{2}$ Laboratório de Ecologia Molecular e Parasitologia Evolutiva, Departamento de Zoologia, Setor de \\ Ciências Biológicas, Universidade Federal do Paraná, Caixa Postal 19073, CEP 81531-980, Curitiba, \\ PR, Brazil. Email: wboeger@gmail.com \\ ${ }^{3}$ Section de Parasitologie, Département de Biologie, Centre de Recherche en Hydrobiologie, B.P. 73, \\ Uvira, Democratic Republic Congo, via B.P. 254, Bujumbura, Burundi. \\ Email: fidelmuterezi@yahoo.fr \\ ${ }^{6}$ ISE-M, UMR5554 CNRS, UR226 IRD, Université Montpellier II - CC 063, F-34095 Montpellier \\ Cedex 5, France. Email: antoine.pariselle@ird.fr \\ ${ }^{7}$ Ichthyology Unit, African Zoology Department, Royal Museum for Central Africa, \\ Leuvensesteenweg 13, B-3080 Tervuren, Belgium. \\ *Corresponding author, Email: maarten.vanhove@bio.kuleuven.be \\ ${ }^{1}$ urn:Isid:zoobank.org:author:F40A361D-F45C-4C91-86AF-115962126120 \\ 2 urn:Isid:zoobank.org:author:318E38BE-6AB8-4D77-BFA9-36F5E8A546E0 \\ ${ }^{3}$ urn:1sid:zoobank.org:author:B521076B-7ED5-4532-8EEA-CB33BF4019F7 \\ ${ }^{4}$ urn:Isid:zoobank.org:author:AC726421-5168-4787-A939-0CCBCBEE5114 \\ ${ }^{5}$ urn:lsid:zoobank.org:author:72A8D565-7DCB-4103-A4B9-84248E88FF4B \\ ${ }^{6}$ urn:Isid:zoobank.org:author:DE920C99-1505-4B1F-A523-E375B1DC6201
}

\begin{abstract}
Iranocichla hormuzensis occupies a biogeographically peculiar position. This endemic of southern Iran is the only Iranian cichlid. While it is phylogenetically related to African oreochromine members of the cichlid family, it remains unclear how it has dispersed into its current range. It is one of the many lasting enigmas of cichlid biogeography. Monogenean fish parasites may provide useful additional information in such cases. Therefore, I. hormuzensis was examined for these flatworms. A gyrodactylid parasite is reported and compared to congeners from the Palearctic and from cichlids. In this way, we verify whether it shows affinities to parasites from fishes that are either biogeographically or phylogenetically close to Iranocichla hormuzensis. The species is new to science and is described as Gyrodactylus jalalii sp. nov. This is the first description of a parasite infecting I. hormuzensis. Because of the fixation method or age of the material, DNA could not be isolated. Due to the lack of genetic data, no conclusions can be drawn on its phylogenetic positioning. Indeed, Gyrodactylus phylogeny cannot be
\end{abstract}


inferred from morphological characteristics alone. Moreover, the congeners phenotypically reminiscent of the new species belong to a Gyrodactylus clade which is highly diverse in geographic range and host choice. Hence, there is no evidence linking the new species to an exclusively African or cichlid-bound Gyrodactylus lineage.

Keywords. Gyrodactylus jalalii sp. nov., Oreochromini, Platyhelminthes, Perciformes, species description.

Vanhove M.P.M., Boeger W.A., Muterezi Bukinga F., Volckaert F.A.M., Huyse T. \& Pariselle A. 2012. A new species of Gyrodactylus (Monogenea, Gyrodactylidae), an ectoparasite from the endemic Iranocichla hormuzensis (Teleostei, Cichlidae), the only Iranian cichlid. European Journal of Taxonomy 29: 1-10. http://dx.doi.org/10.5852/ ejt.2012.30

\section{Introduction}

The fascination and scientific interest that cichlids raise in many scientists and hobbyists is well reviewed by Barlow (2000). This author aptly shows the importance of cichlid fishes in a wide range of fields in evolutionary biology, from ecology to behavior and from developmental biology to speciation. Numbering about 1350 described species, with hundreds remaining to be discovered (Nelson 2006), these "model" fishes are the most species-rich vertebrate family worldwide (Kocher 2004). Counting only described species, Cichlidae is the largest non-ostaryophysan freshwater fish family (Kullander 2003). Its species richness reaches its peak in the more than 900 African representatives. Some relatives to African cichlids occur in the Middle East (belonging to Astatotilapia Pellegrin, 1904; Oreochromis Günther, 1889; Sarotherodon Rüppell, 1852; Tilapia Smith, 1840 and Tristramella Trewavas, 1942) (Werner \& Mokady 2004) and one in Iran. The latter is Iranocichla hormuzensis Coad, 1982, the only representative of the monotypic Iranocichla Coad, 1982. The species was first reported by Behnke (1975) and Saadati (1977) before being formally described (Coad 1982). This southern Iranian endemic cichlid is found in mostly saline riverine systems draining into the Strait of Hormuz (Persian Gulf). The question rises how it arrived in this biogeographically isolated range.

Most cichlid species in the Middle East have congeners among the African "tilapiine" (Oreochromis, Tilapia and Sarotherodon: Schwarzer et al. 2009) or haplochromine (Astatotilapia: Werner \& Mokady 2004) cichlids. Tristramella and Iranocichla, however, are endemic genera. Phylogenetically, they are also placed in Oreochromini, one of the tribes into which "tilapiine" cichlids were split by Schwarzer et al. (2009). Thus, they are closely affiliated to African cichlids. Middle-Eastern cichlids at present only occur in the Levant and these Iranian systems. This fact might indicate a relict-type consequence of a recent (Pleistocene to Recent) aridification event and decrease in temperature (overview in Coad 1982). Furthermore, the Persian Gulf was a river valley between 90,000 and 10,000 years ago. See also Arndt et al. (2003) for a discussion on how the low level of the Mediterranean during Pleistocene episodes is suggested to have allowed freshwater dispersal from the Nile to the Levant. Although those conditions would have allowed dispersal of cichlids, it is also possible that the marine environment would not represent a barrier to the spread of these animals, anyway (see references below). Indeed, occupying mostly saline streams shows that I. hormuzensis is salt-tolerant (Coad 1982). Moreover, several "tilapiines" are known to disperse between rivers through brackish coastal waters (Nelson 2006). Conversely, Murray (2001) favors marine dispersal through the Tethys Sea/Indian Ocean to coastal dispersal in view of the absence of cichlids along the rest of the region's coastlines.

Either way, both freshwater and marine dispersal pathways could explain the presence of this cichlid in waters draining into the Strait of Hormuz. Be it on a local or a global scale, the history behind current cichlid distribution across continents has not been unequivocally unraveled. The roles of intercontinental 
dispersal, on the one hand, and of vicariance (following the break-up of Gondwana) and intra-continental freshwater dispersal, on the other hand, are still highly debated. A potential source of information that remains largely unexplored is the (monogenean) parasite fauna of cichlid species (reviewed in Pariselle et al. 2011). Many parasites have a close association with their host and a shorter generation time than their host, hence providing an alternative perspective on host evolution. Ectoparasitic monogenean flatworms often do not tolerate substantial changes in salinity, as indicated by their distribution and phylogenetic patterns worldwide (although there are exceptions, e.g., this is less the case in Gyrodactylidae, certainly when infecting euryhaline hosts, see below). One might therefore hypothesize that certain freshwater monogeneans rarely survive dispersal through barriers represented by marine environments. Hence, the phylogenetic relationships within a lineage of monogenean ectoparasites reflect both continental patterns and host phylogeny. Freshwater fish hosts most likely retain their monogenean assemblage when dispersing through continental surface waters. Conversely, it was suggested that most freshwater fishes might lose their autochtonous parasites during marine dispersal events. This would allow subsequent recolonisation by "local" parasite species once arriving in freshwater at the other end of a marine barrier (Pariselle et al. 2011).

Here, a Gyrodactylus species parasitizing I. hormuzensis is described. We analyze its affinity to congeners infecting other cichlids and to species known from fishes of the same region. Because of the ability to switch hosts, gyrodactylids are expected to mainly mirror continental affinities rather than the relationships between its host species (Boeger et al. 2003), depending of course on the time-scale and the dispersal routes used. The result might hence shed light on the pathway cichlids used to reach southern Iran.

\section{Material and Methods}

Eight host fishes (fixed and stored in ethanol or in formaldehyde) were retrieved from collections of the Royal Museum for Central Africa (Tervuren, Belgium) (MRAC B2-28-P-1-8). Branchial arches, body, fins and recipient were inspected for parasites under a Wild M8 stereomicroscope. Monogeneans were removed with a dissection needle. They were treated with $10 \%$ sodium dodecyl sulphate for a couple of minutes, before being fixed using ammonium picrate-glycerine (Malmberg 1957) and mounted on a slide under a cover-slip. Measurements were adapted from Shinn et al. (2004) using a Zeiss Axio Imager Z1 microscope at a magnification of $100 \mathrm{x}$ (oil immersion, $10 \mathrm{x}$ ocular) under differential interference contrast, with an AxioCamMR3 camera and AxioVision v.4.2.8 software. For drawings, some specimens were stained with Gomori's trichrome and mounted in Canada balsam for study of their soft anatomy; other specimens were cleared and mounted in Hoyer's or Gray and Wess' media for study of their sclerotized structures (all solutions prepared as in Humason, 1979). Illustrations were prepared with the aid of a digital camera (5 megapixels) and a projector attached to an Olympus BX51 microscope equipped with phase contrast. Taxon and author names in this study follow Eschmeyer (2012) for hosts and MonoDb (http://www.monodb.org) for Monogenea.

\section{Results}

A single (incomplete and therefore unfortunately unidentified) ancyrocephaline monogenean (Dactylogyridae, Ancyrocephalinae) was recovered. All other monogeneans found on the I. hormuzensis specimens belong to Gyrodactylus. 


\author{
Class Monogenea Van Beneden, 1858 \\ Subclass Polyonchoinea Bychowsky, 1937 \\ Order Gyrodactylidea Bychowsky, 1937 \\ Family Gyrodactylidae Van Beneden \& Hesse, 1863 \\ Subfamily Gyrodactylinae Van Beneden \& Hesse, 1863 \\ Genus Gyrodactylus von Nordmann, 1832 \\ Gyrodactylus jalalii sp. nov. \\ urn:Isid:zoobank.org:act:A89D45DC-7CA2-4807-AF2E-E34F9A9BB060
}

Figs 1-2

\title{
Etymology
}

The species epithet, jalalii, honours prof. dr. Behiar Jalali Jafari (1953-2010) (obituary in Shamsi 2010). He was a researcher in aquatic animal health and fish parasitology at the Veterinary Department of the Islamic Azad University (Iran) and a keen student of monogeneans. The authors express the hope that this patronym might serve as an indication for the respect and appreciation this kind man enjoyed from his colleagues.

\section{Type material examined}

Thirty-one specimens, twenty of which (ethanol-preserved) were used for measurements. The holotype (MNHN HEL301) and paratypes (MNHN HEL302-HEL305) are deposited in the Muséum National d'Histoire Naturelle (Paris, France). Paratypes are deposited in the Natural History Museum (London, United Kingdom) (NHMUK 2012.9.10.1-2012.9.10.2), the Royal Museum for Central Africa (Tervuren, Belgium) (MRAC MT: 37711-37713), the Harold W. Manter Laboratory of Parasitology (Lincoln, Nebraska) (HWML-49758) and the United States National Parasite Collection (Beltsville, Maryland) (USNPC 106050).

\section{Type host}

Iranocichla hormuzensis Coad, 1982 (Teleostei, Perciformes, Cichlidae).

\section{Type locality}

Mehran River, Persian Gulf Basin (2009).

\section{Infection site}

Gill filaments, fins, eye.

\section{Description}

(measurements in micrometres $(\mu \mathrm{m})$ and angles in degrees $\left({ }^{\circ}\right)$; average \pm standard deviation, followed by range and number of measurements in parentheses).

Body (Fig. 1A) fusiform, $361.7 \pm 64.4(294.7-528.9 ; n=13)$ long; greatest width $128.1 \pm 21.3(98.8$ $164.0 ; n=13)$. Two head organs provided with single spicule each. Cephalic glands lateral to pharynx. Pharynx composed of two tandem, muscular bulbs. Oesophagus short. Digestive glands lateral to oesophagus. Caeca two, non-confluent, reaching level of germarium. Male copulatory organ (MCO) (Fig. 1B) armed with a broad-based, robust, recurved, apical spine $5.7 \pm 1.1(4.5-7.6 ; n=8)$ long, 5-7 smaller flanking spines in a single row, becoming more slender from the terminal over the subterminal towards the median ones (terminology of García-Vásquez et al. 2007). Testis dorsal to germarium. 
Germarium immediately posterior to uterus. Uterus with up to 2 embryos. Unicellular glands lateral to terminations of caeca, posterior to germarium. Haptor elongate (Fig. 1A, D). Anchor (hamulus) (Fig. 1E) $79.9 \pm 4.4(70.4-86.3 ; n=20)$ long; point $33.9 \pm 2.3(28.3-38.4 ; n=19)$ long; base (superficial root) $28.2 \pm 3.9(19.7-33.1 ; n=20)$ long; deep root knob-like; groove proximally at the base of the anchor, serving as articulation to superficial (ventral) bar; shaft $49.5 \pm 2.2(45.6-55.0 ; n=19)$ long, proximally $10.2 \pm 0.8(8.7-11.9 ; n=20)$ wide, distally $5.7 \pm 0.8(4.5-7.4 ; n=19)$ wide; point sharply curved, with aperture $30.5 \pm 2.5(26.2-35.4 ; n=20)$, aperture angle $42.7 \pm 3.2(36.9-47.3 ; n=19)$, inner aperture angle $46.9 \pm 5.3(30.1-53.3 ; n=19)$; inner curve length $1.9 \pm 0.8(0.7-3.3 ; n=18)$ with point curve angle $9.5 \pm 4.5(4.2-22.9 ; n=18)$. Ventral bar (Fig. 1D) $33.5 \pm 2.5(29.8-37.7 ; n=20)$ wide, 44.1 $\pm 3.9(36.4-49.8 ; n=20)$ long; anterior bilateral processes slender, pronounced and $6.0 \pm 1.1$ (4.2-7.8; $n=20)$ long with process to mid-length $10.4 \pm 1.7(7.5-14.8 ; n=20)$. Median portion of ventral bar
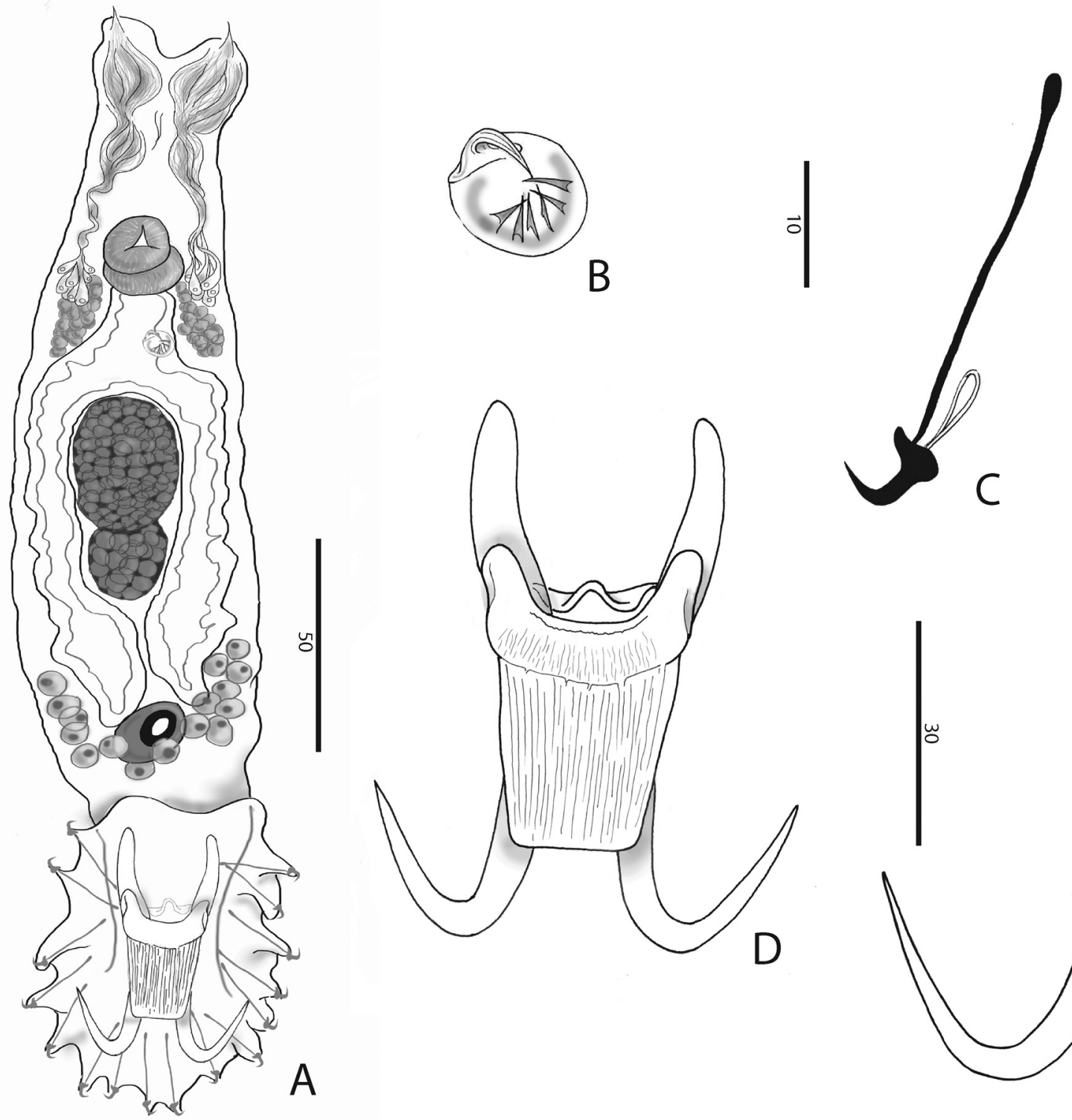

Fig. 1. Gyrodactylus jalalii sp. nov. A. whole mount. B. male copulatory organ. C. marginal hook. D. anchor-bar complex. E. anchor. Scale bars represent $50 \mu \mathrm{m}$ (whole mount), $10 \mu \mathrm{m}$ (marginal hook, $\mathrm{MCO}$ ) or $30 \mu \mathrm{m}$ (anchor, anchor-bar complex). 
$8.3 \pm 1.2(5.7-9.8 ; n=20)$ long; shield (ventral bar membrane) $25.4 \pm 3.3(19.8-30.1 ; n=20)$ long, subrectangular, clearly striated in much the same way as bar proper. Deep (dorsal) bar $23.0 \pm 2.8$ (18.9$29.9 ; n=20$ ) wide, medially constricted and at connection to deep root of anchors. Marginal hook (Figs 1C, 2A, B) $31.8 \pm 4.1(25.8-43.5 ; n=20)$ long, shank with small distal bulb, $26.9 \pm 4.1$ (22.1-40.0; $n=20)$ long; sickle (hooklet) $5.4 \pm 0.3(4.5-6.1 ; n=20)$ long, $4.3 \pm 0.4(3.6-5.1 ; n=20)$ wide proximally, $4.5 \pm 0.5(3.8-5.3 ; n=20)$ distally; toe depressed, $2.0 \pm 0.4(1.4-3.0 ; n=20)$ long; convex platform; concave base; round keel; point of sickle proper as long as shaft, forming an angle of about $90^{\circ}$ from each other; aperture $5.2 \pm 0.5(4.5-6.4 ; n=20)$; instep/arch height $0.6 \pm 0.1(0.4-0.8 ; n=20)$.

\section{Remarks}

In comparison with congeners parasitizing cichlids, the striated ventral bar proper and shield, as well as the conspicuous ventral bar processes, seem most reminiscent to G. zimbae Vanhove, Snoeks, Huyse \& Volckaert, 2011. However, the anterolateral processes of the ventral bar of G. zimbae are more earshaped. In G. zimbae, the ventral bar shield is slender and rounded and the hooklet lacks an arched base (versus subrectangular shield and concave hooklet base in G. jalalii sp. nov.). Other cichlid Gyrodactylus with relatively large ventral bar processes include G. shariff Cone, Arthur \& Bondad-Reantaso, 1995 and G. yacatli García-Vásquez, Hansen, Christison, Bron \& Shinn, 2011. Just like in G. jalalii sp. nov., point and shaft of their hooklet sickle are at a right angle. These species are easily distinguished from G. jalalii sp. nov. by the smaller size of their haptoral sclerites and the ventral bar in particular (e.g., anchor 47.5 and 48.4 long, ventral bar shield 14.4 and 8.5 long, in G. shariffi and G. yacatli respectively) (García-Vásquez et al. 2011). It should be noted, however, that these two species were described from cultured Oreochromis niloticus (Linnaeus, 1758) in the Philippines, resp. Mexico. The authors describing G. yacatli consider accidental infection or host switch a more likely scenario than an African origin (García-Vásquez et al. 2011). Hence, G. zimbae seems to be the most comparable cichlid parasite whose natural distribution is certainly African.

Comparison to Palearctic congeners followed Pugachev et al. (2009). The rather large ventral bar processes, in combination with the length of the marginal hooks, and MCO armed with one large apical spine and one row of smaller spines of similar size, resemble the morphology of G. ophiocephali Gussev, 1955 from Channa argus (Cantor, 1842) (Perciformes: Channidae) and Cyprinus carpio Linnaeus, 1758 (Cypriniformes, Cyprinidae), and to G. tokobaevi Ergens \& Karabekova, 1980 from Gymnodiptychus
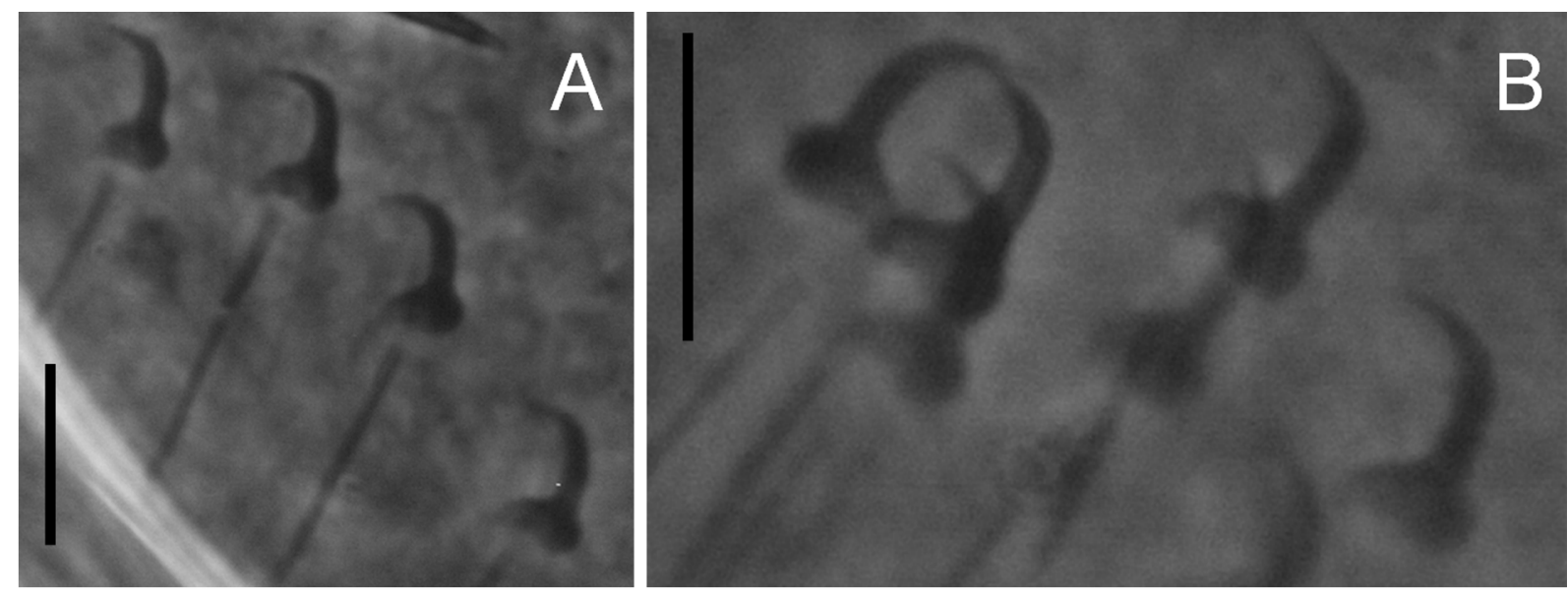

Fig. 2. A. micrograph detailing the marginal hooks of Gyrodactylus jalalii sp. nov. (photographed in utero, with an Olympus BX50 microscope, using phase contrast, and Olympus DP-soft v.3.2 software). B. idem, detail. Scale bars represent $8 \mu \mathrm{m}$. 
dybowskii (Kessler, 1874) (Cypriniformes, Cyprinidae). However, in G. ophiocephali and G. tokobaevi, the processes are longer than the ventral bar proper (median length, i.e., without the shield), which is not the case in $G$. jalalii sp. nov. Elongate antero-lateral processes, albeit not longer than the ventral bar proper, are also found in G. hrabei Ergens, 1957 and G. mariannae Winger, Hansen, Bachmann \& Bakke, 2008, parasites of Cottus Linnaeus, 1758 spp. (Scorpaeniformes, Cottidae). These species, however, have a comparatively shorter anchor root than G. jalalii sp. nov. The longitudinal striae on the ventral bar shield as well as an overlap in size of anchor and marginal hook are reminiscent of $G$. lotae Gussev, 1953 from Lota lota (Linnaeus, 1758) (Gadiformes, Lotidae). This species can be distinguished from G. jalalii sp. nov. because the new species has blunter and larger ventral bar processes, and a marginal hook sickle toe which joins smoothly into the platform, whereas this transition leaves a sharp "bump" in the platform in G. lotae.

\section{Discussion}

Just as Barlow (2000) praises cichlids, early students of Gyrodactylus expressed their high expectations for the scientific interest of these flatworms, as they recognized the species richness of this genus and the amount of work and skill it would take to adequately study it (von Nordmann 1832; Van Beneden \& Hesse 1863). Given this scientifically challenging position of both cichlids and gyrodactylids, G. jalalii sp. nov. was described, a monogenean ectoparasite of the only Iranian cichlid I. hormuzensis. To the best of our knowledge, it is the first parasite to be formally described from this fish species. It brings the total number of Gyrodactylus species described from cichlid hosts to 15 (Paperna 1979; Boeger \& Popazoglo 1995; Christison et al. 2005; Přikrylová et al. 2009, 2012; García-Vásquez et al. 2011; Vanhove et al. 2011).

Jalali et al. (2001) observed that the highly distinct zoogeographical regions of Iran and the high degree of endemicity of its freshwater fishes gave rise to a diverse monogenean fauna. These authors did not mention Gyrodactylus in their overview. Indeed, Jalali et al. (2005) noted that representatives of this genus from the endemic freshwater fishes of the country are basically unknown and undescribed. They did not report gyrodactylids from Iranocichla. This cichlid seems distributed mostly in the Mesopotamian faunal region of Iran, from which Jalali et al. (2001) reported a rather unexplored, endemic and specific monogenean fauna, containing both Palearctic and African elements. For this reason, G. jalalii sp. nov. was compared to Palearctic and African congeners. Morphological similarities are unsurprisingly apparent (see above). Haptoral morphology alone does not allow reliable phylogenetic inferences for species of Gyrodactylus (Ziętara \& Lumme 2004). Unfortunately, we were unsuccessful in amplifying DNA from G. jalalii sp. nov. Hence, genetic data are at present unavailable for the new species, as is the case for several congeners used in this comparison. However, it is noteworthy that some of the aforementioned species show affinities in molecular phylogenetic reconstructions. Indeed, G. mariannae is close to G. hrabei, which is genetically similar to G. flesi Malmberg, 1957 (Winger et al. 2008). This species clusters with G. lotae and G. zimbae, among other species, in a Gyrodactylus clade containing representatives from various subgenera as defined by Malmberg (1970) and from many continents and host taxa (Ziętara \& Lumme 2004; Vanhove et al. 2011). Despite the need for genetic data, assuming, that G. jalalii sp. nov. is indeed related to this lineage, this fact alone does not make it a very suitable candidate to provide information on biogeographical dispersal pathways of cichlid fishes. Indeed, several species also belonging to this diverse clade have been observed to show a broad salinity tolerance (G. branchialis Huyse, Malmberg \& Volckaert, 2004 and G. ostendicus Huyse \& Malmberg, 2004: Huyse et al. 2006) or the ability to switch infection sites (G. arcuatus Bychowsky, 1933: Raeymaekers et al. 2008) or hosts (G. arcuatus: Huyse et al. 2003, 2006). However, while there is hence no proof that $G$. jalalii sp. nov. belongs to an exclusively African or cichlid-infecting lineage, this broad ecological spectrum enhances the potential of these parasites as biogeographical markers, conditional to the availability of molecular data. 


\section{Acknowledgements}

M.P.M.V. is a PhD fellow, and T.H. a post-doctoral fellow, of the Research Foundation - Flanders (FWOVlaanderen). W.A.B. is a research fellow of $\mathrm{CNPq}-$ Brazil. F.M.B. received financial support from IRD (BEST) for a training session in Belgium, during which part of the morphological work for this study was performed. Prof. L. Schoofs, Prof. L. Arckens and Dr. E. Meelkop (KU Leuven) are thanked for the use of the ZEISS microscope, and Dr. Sh. Shamsi (Charles Sturt University, Wagga Wagga) for help in obtaining literature. S. Asadollah (Isfahan University of Technology) and the late Prof. B. Jalali Jafari (Islamic Azad University, Teheran) are acknowledged for kindly providing us with Iranocichla specimens and with information on this fish. Two anonymous reviewers provided useful suggestions.

\section{References}

Arndt A., Van Neer W., Hellemans B., Robben J., Volckaert F. \& Waelkens M. 2003. Roman trade relationships at Sagalassos (Turkey) elucidated by ancient DNA of fish remains. Journal of Archaeological Science 30: 1095-1105. http://dx.doi.org/10.1016/S0305-4403(02)00204-2

Barlow G.W. 2000. The cichlid fishes. Nature's grand experiment in evolution. Perseus Publishing, Cambridge, Massachusetts.

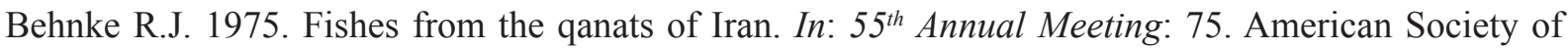
Ichthyologists and Herpetologists, Williamsburg, Virginia.

Boeger W.A. \& Popazoglo F. 1995. Neotropical Monogenoidea. 23. Two new species of Gyrodactylus (Gyrodactylidae) from a cichlid and an erythrinid fish of Southeastern Brazil. Memórias do Instituto Oswaldo Cruz 90 (6): 689-694. http://dx.doi.org/10.1590/S0074-02761995000600006

Boeger W.A., Kritsky D.C. \& Pie M.R. 2003. Context of diversification of the viviparous Gyrodactylidae (Platyhelminthes, Monogenoidea). Zoologica Scripta 32 (5): 437-448. http://dx.doi.org/10.1046/j.14636409.2003.00130.x

Christison K.W., Shinn A.P. \& van As J.G. 2005. Gyrodactylus thlapi n. sp. (Monogenea) from Pseudocrenilabrus philander philander (Weber) (Cichlidae) in the Okavango Delta, Botswana. Systematic Parasitology 60 (3): 165-173. http://dx.doi.org/10.1007/s11230-004-6342-x

Coad B. 1982. A new genus and species of cichlid endemic to southern Iran. Copeia 1: 28-37. http:// www.jstor.org/stable/1444264

Eschmeyer W.N. (ed.) 2012. Catalog of Fishes electronic version. Available from http://research. calacademy.org/research/ichthyology/catalog/fishcatmain.asp [accessed 11 Apr. 2012]

García-Vásquez A., Hansen H. \& Shinn A.P. 2007. A revised description of Gyrodactylus cichlidarum Paperna, 1968 (Gyrodactylidae) from the Nile tilapia, Oreochromis niloticus niloticus (Cichlidae), and its synonymy with G. niloticus Cone, Arthur \& Bondad-Reantaso, 1995. Folia Parasitologica 54: 129140.

García-Vásquez A., Hansen H., Christison K.W., Bron J.E. \& Shinn A.P. 2011. Description of three new species of Gyrodactylus von Nordmann, 1832 (Monogenea) parasitizing Oreochromis niloticus niloticus (L.) and O. mossambicus (Peters) (Cichlidae). Acta Parasitologica 56 (1): 20-33. http://dx.doi. org/10.2478/s11686-011-0005-2

Humason G.L. 1979. Animal Tissue Techniques. Fourth edition. Freeman and Company, San Francisco.

Huyse T., Audenaert V. \& Volckaert F.A.M. 2003. Speciation and host-parasite relationships in the parasite genus Gyrodactylus (Monogenea, Platyhelminthes) infecting gobies of the genus Pomatoschistus (Gobiidae, Teleostei). International Journal for Parasitology 33 (14): 1679-1689. http://dx.doi. org/10.1016/S0020-7519(03)00253-4 
Huyse T., Pampoulie C., Audenaert V. \& Volckaert F.A.M. 2006. First report of Gyrodactylus spp. (Platyhelminthes: Monogenea) in the western Mediterranean sea: molecular and morphological descriptions. Journal of Parasitology 92 (4): 682-690. http://dx.doi.org/10.1645/GE-690R.1

Jalali B., Shamsi Sh. \& Imanzadeh F. 2001. Specific composition and morphological pecularities of endemic monogenean parasites of freshwater fishes of Iran. Iranian Journal of Fisheries Sciences 3 (1): $13-22$.

Jalali B., Shamsi Sh. \& Barzegar M. 2005. Occurrence of Gyrodactylus spp (Monogenea: Gyrodactylidae) from Iranian freshwater fishes. Iranian Journal of Fisheries Sciences 4 (2): 19-30.

Kocher T.D. 2004. Adaptive evolution and explosive speciation: the cichlid fish model. Nature Reviews Genetics 5: 288-298. http://dx.doi.org/10.1038/nrg1316

Kullander S.O. 2003. Family Cichlidae (cichlids). In: Reis R.E., Kullander S.O. \& Ferraris C.J. Jr. (eds) Checklist of the freshwater fishes of South and Central America: 605-654. EDIPUCRS, Porto Alegre.

Malmberg G. 1957. On the occurrence of Gyrodactylus on Swedish fishes. Skrifter utgivna av Södra Sveriges Fiskeriföreningen 1956: 19-76. [in Swedish]

Malmberg G. 1970. The excretory systems and the marginal hooks as basis for the systematics of Gyrodactylus (Trematoda, Monogenea). Arkiv för zoologi 2: 1-235.

Murray A.M. 2001. The fossil record and biogeography of the Cichlidae (Actinopterygii: Labroidei). Biological Journal of the Linnean Society 74 (4): 517-532. http://dx.doi.org/10.1111/j.1095-8312.2001. $\underline{\mathrm{tb} 01409 . \mathrm{x}}$

Nelson J.S. 2006. Fishes of the world. Fourth edition. John Wiley \& Sons Inc., Hoboken, New Jersey.

Paperna I. 1979. Monogenea of inland water fish in Africa. Annalen Koninklijk Museum voor MiddenAfrika Zoologische Wetenschappen 226, Koninklijk Museum voor Midden Afrika, Tervuren.

Pariselle A., Boeger W.A., Snoeks J., Bilong Bilong C.F., Morand S. \& Vanhove M.P.M. 2011. The monogenean parasite fauna of cichlids: a potential tool for host biogeography. International Journal of Evolutionary Biology 2011: 471-480. http://dx.doi.org/10.4061/2011/471480

Přikrylová I., Matějusová I., Musilová N. \& Gelnar M. 2009. Gyrodactylus species (Monogenea: Gyrodactylidae) on the cichlid fishes of Senegal, with the description of Gyrodactylus ergensi n. sp. from Mango tilapia, Sarotherodon galilaeus L. (Teleostei: Cichlidae). Parasitology Research 106: 1-6. http://dx.doi.org/10.1007/s00436-009-1600-0

Přikrylová I., Blažek R. \& Gelnar M. 2012. Gyrodactylus malalai sp. nov. (Monogenea, Gyrodactylidae) from Nile tilapia, Oreochromis niloticus (L.) and Redbelly tilapia, Tilapia zillii (Gervais) (Teleostei, Cichlidae) in the Lake Turkana, Kenya. Acta Parasitologica 57 (2): 122-130. http://dx.doi.org/10.2478/ $\underline{\mathrm{s} 11686-012-0017-6}$

Pugachev O.N., Gerasev P.I., Gussev A.V., Ergens R. \& Khotenowsky I. 2009. Guide to Monogenoidea of freshwater fish of Palaearctic and Amur regions. Ledizione-LediPublishing, Milan.

Raeymaekers J.A.M., Huyse T., Maelfait H., Hellemans B. \& Volckaert F.A.M. 2008. Community structure, population structure and topographical specialisation of Gyrodactylus (Monogenea) ectoparasites living on sympatric stickleback species. Folia Parasitologica 55: 187-196.

Schwarzer J., Misof B., Tautz D. \& Schliewen U.K. 2009. The root of the East African cichlid radiations. BMC Evolutionary Biology 9: 186. http://dx.doi.org/10.1186/1471-2148-9-186

Shamsi Sh. 2010. Profile: Behiar Jalali (1953-2010). Systematic Parasitology 76: 235-236. http://dx.doi. org/10.1007/s11230-010-9251-1 
Shinn A.P., Hansen H., Olstad K., Bachmann L. \& Bakke T.A. 2004. The use of morphometric characters to discriminate specimens of laboratory-reared and wild populations of Gyrodactylus salaris and G. thymalli (Monogenea). Folia Parasitologica 51: 239-252.

Van Beneden P.-J. \& Hesse C.E. 1863. Recherches sur les Bdellodes ou Hirudinées et les Trématodes Marins. Académie Royale de Belgique, Brussels.

Vanhove M.P.M., Snoeks J., Volckaert F.A.M. \& Huyse T. 2011. First description of monogenean parasites in Lake Tanganyika: the cichlid Simochromis diagramma (Teleostei, Cichlidae) harbours a high diversity of Gyrodactylus species (Platyhelminthes, Monogenea). Parasitology 138 (3): 364-380. http://dx.doi.org/10.1017/S0031182010001356

von Nordmann A. 1832. Mikrographische Beiträge zur Naturgeschichte der wirbellosen Thiere. Erstes Heft. G. Reimer, Berlin.

Werner N.Y. \& Mokady O. 2004. Swimming out of Africa: mitochondrial DNA evidence for late Pliocene dispersal of a cichlid from Central Africa to the Levant. Biological Journal of the Linnean Society 82 (1): 103-109. http://dx.doi.org/10.1111/j.1095-8312.2004.00321.x

Winger A.C., Hansen H., Bachmann L. \& Bakke T.A. 2008. Gyrodactylus species (Monogenea) infecting alpine bullhead (Cottus poecilopus Heckel, 1837) in Norway and Slovakia, including the description of Gyrodactylus mariannae sp. nov. Acta Parasitologica 53 (3): 240-250. http://dx.doi.org/10.2478/ s11686-008-0045-4

Ziętara M.S. \& Lumme J. 2004. Comparison of molecular phylogeny and morphological systematics in fish parasite genus Gyrodactylus Nordmann, 1832 (Monogenea, Gyrodactylidae). Zoologica Poloniae 49: 5-28.

Manuscript received: 17 May 2012

Manuscript accepted: 7 November 2012

Published on: 30 November 2012

Topic editor: Rudy Jocqué

Printed versions of all papers are also deposited in the libraries of the institutes that are members of the EJT consortium: Muséum National d'Histoire Naturelle, Paris, France; National Botanic Garden of Belgium, Meise, Belgium; Royal Museum for Central Africa, Tervuren, Belgium; Natural History Museum, London, United Kingdom; Royal Belgian Institute of Natural Sciences, Brussels, Belgium; Natural History Museum of Denmark, Copenhagen, Denmark. 